\title{
Handbook of Florida Agricultural Laws: Environmental and Conservation Regulations ${ }^{1}$
}

\author{
Michael T. Olexa, lan Alperstein, and Joseph Fischer²
}

\section{Preface}

This handbook is designed to provide an accurate, current, and authoritative summary of the principal Florida laws that directly or indirectly relate to agriculture. It provides a basic overview of the many rights and responsibilities that farmers and farm land owners have under Florida laws. Many readers may value this handbook because it informs them about these rights and responsibilities, and it provides them with good contacts for more detailed information. However, the reader should be aware that because the laws, administrative rulings, and court decisions on which this handbook is based are subject to constant revision, portions of this handbook could become outdated at any time. Many details of cited laws are also left out due to space limitations.
This handbook is distributed with the understanding that the authors are not engaged in rendering legal or other professional advice. It is not all-inclusive in providing information to achieve compliance with laws and regulations governing the practice of agriculture. For these reasons, the use of these materials by any person constitutes an agreement to hold harmless the authors, UF/IFAS, the Agricultural Law Center, and the University of Florida for any liability claims, damages, or expenses that may be incurred by any person as a result of reference to or reliance on the information contained in this handbook.

1. This is EDIS document FE118, a publication of the Department of Food and Resource Economics, Florida Cooperative Extension Service, IFAS, University of Florida, Gainesville, FL. FE118 is part of Circular 1224, Handbook of Florida Agricultural Laws. First published November 1999, and revised April 2004 and December 2007. Please visit the EDIS website at http://edis.ifas.ufl.edu.

2. Michael T. Olexa, Professor, Department of Food and Resource Economics, and Director, UF/IFAS Agricultural Law Center, Member, The Florida Bar, Florida Cooperative Extension Service, UF/IFAS, University of Florida, Gainesville, FL; Ian Alperstein, third-year law student, Levin College of Law, University of Florida, Gainesville, FL; and Joseph Fischer, graduate, Levin College of Law, University of Florida, and members, The Florida Bar.

This publication is designed to provide accurate, current and authoritative information on the subject. However, since the laws, administrative rulings, and court decisions on which it is based are subject to constant revision, portions of this publication could become outdated at any time. This publication is distributed with the understanding that the authors are not engaged in rendering legal or other professional advice, and the information contained herein should not be regarded, or relied upon, as a substitute for professional advice. For these reasons, the utilization of these materials by any person constitutes an agreement to hold harmless the authors, UF/IFAS, and the University of Florida for any liability, claims, damages, or expenses that may be incurred by any person as a result of reference to or reliance on the information contained in this document.

Acknowledgment: The authors are indebted to the personnel of both state and federal agencies who gave of their time and advice in the preparation of this handbook. The authors are also indebted to Mr. Richard Budell of the Office of Agricultural Water Policy of the Florida Department of Agriculture and Consumer Services for providing support.

The Institute of Food and Agricultural Sciences (IFAS) is an Equal Opportunity Institution authorized to provide research, educational information and other services only to individuals and institutions that function with non-discrimination with respect to race, creed, color, religion, age, disability, sex, sexual orientation, marital status, national origin, political opinions or affiliations. U.S. Department of Agriculture, Cooperative Extension Service, University of Florida, IFAS, Florida A. \& M. University Cooperative Extension Program, and Boards of County Commissioners Cooperating. Larry Arrington, Dean 


\section{A Brief Note on Florida Laws and Rule Making}

The Florida laws described in this handbook were passed by the state legislature and have become valid state laws. The appropriate state agency then wrote specific rules based on each law. These rules are what the state agencies use to enforce the law. For most laws in this handbook, that agency is the Department of Agriculture and Consumer Services (DACS). Florida legislated laws, also called statutes, are organized into chapters. A chapter is divided even further into specific statutes. For example, Chapter 601 (Florida Citrus Code) contains dozens of sections covering topics ranging from marketing, inspection standards, and processing to prohibitions on the use of certain chemicals for citrus fruit. Other chapters may deal with a narrower subject and have far fewer sections. As noted above, the specific rules for each of these sections are written by a designated state agency, and generally go into greater detail. You can view the Florida Statutes online at http://www.flsenate.gov/statutes.

\section{Introduction}

This handbook can be used to learn which Florida laws apply to a particular agricultural project or subject, and to find the name, address, and telephone number of a state office that can provide more specific information or services. Created for readers with no prior experience in the law, the handbook is designed as a necessary first step in recognizing which agricultural activities merit special attention because of their implications to agriculture. The handbook also provides an introduction to the crucial agencies and statutes which govern agricultural law.

The online handbook is divided into a Table of Contents, Index, and six fact sheets. The Table of Contents gives general and specific areas of Florida laws related to agriculture and the number of the fact sheet where that topic can be found. The six fact sheets are as follows: FE114, General Agriculture-Related Laws; FE115, Animal Husbandry; FE116, Crops and Products; FE117, Related Non-Crop or Product Agricultural Topics; FE118, Environmental and Conservation Regulations; and FE119, Taxation and Property Rights Related to Agricultural Land. The user can find the specific laws by using either the Table of Contents (FE113) or the Index (FE122).

Below is an example of using the handbook if your area of interest is farming exotic animals such as ostriches.

To use the Table of Contents:

1. Find "Animal Husbandry" in the Table of Contents (FE113).

2. Within the Animal Husbandry area locate "Livestock-Exotic Animals". Follow the link to FE115: Animal Husbandry.

3. In FE115, read the "General Descriptions" and "Related References, Details, and Exceptions" columns for both laws under "Livestock-Exotic Animals". Determine if the information answers the questions or if more information is needed.

4. If the user wants more information regarding the general farming or inspection and slaughter of an exotic animal (e.g., ostriches), locate the appropriate state office telephone number and address. The primary contact agency information is listed at the end of the fact sheet, along with abbreviation information.

To use the Index:

Look up "ostriches" in the Index (FE122). The index leads the reader to the location for information about the culture and inspection/slaughter of ostriches. Follow steps 3 and 4 above to find the contact information.

\section{Division of the Tables}

The table in each fact sheet has five columns of information. The first column, "Statute / Law (description)," either provides the law's name or a general description when no name is available. The second column, "Florida Statute Number", lists either a chapter number when an entire chapter relates to a particular topic, a range of sections, or a single 
specific section. At times, a single chapter number may have many more laws than a range. For example, sections 593.101 to 593.117 cover a narrower field, the control of cotton boll weevil, than the larger Chapter 601 on citrus fruit. The chapter and section number in all columns are presented without the typical abbreviations or symbols.

Columns 3 and 4 provide brief descriptions and related references, details, and exceptions. This information is highly condensed. As such, not all information is provided. The authors have attempted to include the most relevant aspects of each listed law. Additional information can be obtained by contacting the offices noted in the final column, "Primary Contact Agencies." As noted above, the primary contact information is listed at the end of the fact sheet. The reader will find that the state and federal agencies are unquestionably the best targets for specific questions, as they are in close touch with both the formal and practical considerations of the areas that they regulate.

This publication can be improved with your ideas and suggestions. Comments regarding any areas which may have been omitted, but deserve inclusion, are particularly valuable. Reader feedback is a necessary ingredient to complete any successful future editions. Please send your comments or suggestions to:

Michael T. Olexa

Director, Agricultural Law Center

Food and Resource Economics Department

Post Office Box 110240

University of Florida

Gainesville, FL 32611-0240

Fax (352) 392-9898 


\begin{tabular}{|c|c|c|c|c|}
\hline \multicolumn{5}{|c|}{ V. Florida Agricultural Laws: Environmental and Conservation Regulations } \\
\hline $\begin{array}{l}\text { Statute / Law } \\
\text { (description) }\end{array}$ & $\begin{array}{l}\text { Florida } \\
\text { Statute } \\
\text { Number }\end{array}$ & General Description & $\begin{array}{c}\text { Related References, Details, } \\
\text { and Exceptions }\end{array}$ & $\begin{array}{l}\text { Primary } \\
\text { Contact } \\
\text { Agencies }\end{array}$ \\
\hline \multicolumn{5}{|c|}{ A. Uses and Storage of Water } \\
\hline $\begin{array}{l}\text { General law } \\
\text { regarding } \\
\text { permitting the } \\
\text { consumptive } \\
\text { uses of water }\end{array}$ & $\begin{array}{l}373.203- \\
373.250\end{array}$ & $\begin{array}{l}\text { Requires permits for water } \\
\text { uses above specified } \\
\text { amounts from wells and } \\
\text { surface waters. Specific } \\
\text { requirements/permitting are } \\
\text { responsibility of WMDs. }\end{array}$ & $\begin{array}{l}\text { DEP or WMD can formulate plans for } \\
\text { periods of water shortage, which may } \\
\text { modify permitted consumption by a } \\
\text { water user (373.246). During water } \\
\text { shortages, applies to withdrawals } \\
\text { from surface waters and aquifers. See } \\
2004-381 \text {, section 4, establishing } \\
\text { 373.2234, requiring WMDs to identify } \\
\text { "preferred water supply sources for } \\
\text { consumptive uses" that provides } \\
\text { substantial new water supplies without } \\
\text { adverse impact. Consumptive use } \\
\text { permits for use of such water sources } \\
\text { must be granted for a } 20 \text {-year period if } \\
\text { all other obligations are met. See } \\
2004-381 \text {, section } 8 \text {, establishing } \\
373.277, \text { requiring WMDs and other } \\
\text { stakeholders to formulate a } \\
\text { comprehensive statewide water } \\
\text { conservation program, which may } \\
\text { impact consumptive use permits. See } \\
2004-381 \text {, section } 6 \text {, establishing } \\
\text { 373.228, requiring WMDs and other } \\
\text { stakeholders to develop "landscape } \\
\text { irrigation and xeriscape design } \\
\text { standards for new construction" for } \\
\text { improved water efficiency. }\end{array}$ & $\begin{array}{l}\text { DEP } \\
\text { WMD }\end{array}$ \\
\hline $\begin{array}{l}\text { Law regarding } \\
\text { construction, } \\
\text { repair, and } \\
\text { abandonment } \\
\text { of wells }\end{array}$ & $\begin{array}{l}373.302- \\
373.342\end{array}$ & $\begin{array}{l}\text { Regulates well construction, } \\
\text { repair, and abandonment, } \\
\text { and requires certification of } \\
\text { well contractors. }\end{array}$ & $\begin{array}{l}\text { Permits are not required for domestic } \\
\text { consumption by individual users for } \\
\text { private shallow wells and for certain } \\
\text { other uses, but wells must comply } \\
\text { with local and state well construction } \\
\text { requirements (373.326). County } \\
\text { health departments (25) should be } \\
\text { consulted for well placement. } \\
\text { Pollution of aquifer with hazardous } \\
\text { waste through wells involves federal } \\
\text { CERCLA/Superfund laws for } \\
\text { environmental cleanup. }\end{array}$ & $\begin{array}{l}\text { DEP } \\
\text { WMD }\end{array}$ \\
\hline
\end{tabular}




\begin{tabular}{|c|c|c|c|c|}
\hline \multicolumn{5}{|c|}{ V. Florida Agricultural Laws: Environmental and Conservation Regulations } \\
\hline $\begin{array}{l}\text { Statute / Law } \\
\text { (description) }\end{array}$ & $\begin{array}{l}\text { Florida } \\
\text { Statute } \\
\text { Number }\end{array}$ & General Description & $\begin{array}{l}\text { Related References, Details, } \\
\text { and Exceptions }\end{array}$ & $\begin{array}{l}\text { Primary } \\
\text { Contact } \\
\text { Agencies }\end{array}$ \\
\hline $\begin{array}{l}\text { Law excluding } \\
\text { agricultural } \\
\text { activities from } \\
\text { DEP dredge } \\
\text { and fill } \\
\text { permits }\end{array}$ & 403.927 & $\begin{array}{l}\text { Recognizes the value of } \\
\text { farming and forestry, and } \\
\text { excludes agricultural } \\
\text { activities and agricultural } \\
\text { water management systems } \\
\text { from typical DEP dredge and } \\
\text { fill permit requirements } \\
\text { required under } 403.087 \text {. }\end{array}$ & $\begin{array}{l}\text { Exempts farming operations from one } \\
\text { type of permitting, and authorizes } \\
\text { WMDs to regulate water discharge } \\
\text { from agricultural operations by way of } \\
\text { MSSW (Management and Storage of } \\
\text { Surface Water) permits. }\end{array}$ & $\begin{array}{l}\text { DEP } \\
\text { WMD }\end{array}$ \\
\hline $\begin{array}{l}\text { Laws regarding } \\
\text { management } \\
\text { and storage of } \\
\text { surface waters } \\
\text { (MSSW) }\end{array}$ & $\begin{array}{l}373.403- \\
373.468\end{array}$ & $\begin{array}{l}\text { Gives rule-making authority } \\
\text { to protect water resources. } \\
\text { Requires MSSW permit for } \\
\text { structures that can connect } \\
\text { to, draw water from, or drain } \\
\text { water into bodies of surface } \\
\text { water (e.g., impoundments, } \\
\text { dams, reservoirs, and } \\
\text { stormwater systems). Need } \\
\text { special permits for wetlands } \\
\text { generally (373.414), } \\
\text { Miami-Dade County Lake } \\
\text { Belt (373.41942), the } \\
\text { Everglades (373.4592) [note: } \\
\text { lands used for agricultural } \\
\text { purposes without the areas } \\
\text { as defined by } 373.4592 \text { may } \\
\text { be subject to an agricultural } \\
\text { privilege tax, such as the } \\
\text { Everglades Agricultural } \\
\text { privilege tax, 373.4592(6)], } \\
\text { Florida Bay (373.4593), Lake } \\
\text { Okeechobee (373.4595), } \\
\text { Geneva Freshwater Lens } \\
\text { (373.4595), Lake Apopka } \\
\text { (373.461), Lake Panasofkee } \\
\text { (373.465), and the Harris } \\
\text { Chain of Lakes ( } 373.467) \text {. }\end{array}$ & $\begin{array}{l}\text { These laws do not apply to the normal } \\
\text { practices of agriculture, forestry, } \\
\text { floriculture, or horticulture that merely } \\
\text { alter the contour of the land } \\
\text { (373.406(2)), or to certain aspects of } \\
\text { agricultural closed systems } \\
\text { (373.406(3)). Permits are needed for } \\
\text { structures that impact surface waters, } \\
\text { such as dredging or filling canals. } \\
\text { Authorizes the DEP or WMDs to } \\
\text { require headgates, valves, and } \\
\text { measuring devices to regulate and to } \\
\text { measure water flow being discharged } \\
\text { or diverted, and prohibits tampering } \\
\text { with the devices (373.409). Allows for } \\
\text { mitigation and mitigation banking to } \\
\text { offset activities that degrade surface } \\
\text { waters (373.4135). Permits for } \\
\text { wetland activities are obtained from } \\
\text { the U.S. Army Corps of Engineers and } \\
\text { DEP and are required. Following best } \\
\text { management practices (BMP) } \\
\text { generally assures compliance after } \\
\text { issuance of permit. Requires permit } \\
\text { from WMD to abandon most water } \\
\text { management structures ( } 373.426 \text { ). } \\
373.4143-373.4144 \text { requires } \\
\text { consolidation of federal and state } \\
\text { permitting procedures/plans dealing } \\
\text { with wetlands and navigable waters. }\end{array}$ & $\begin{array}{l}\text { DEP } \\
\text { WMD }\end{array}$ \\
\hline $\begin{array}{l}\text { Law regarding } \\
\text { wastewater } \\
\text { use for spray } \\
\text { irrigation }\end{array}$ & 403.135 & $\begin{array}{l}\text { Relieves good faith user of } \\
\text { wastewater from liability due } \\
\text { to damages from proper } \\
\text { application of wastewater } \\
\text { that was permitted and } \\
\text { intended for spray irrigation } \\
\text { use. }\end{array}$ & $\begin{array}{l}\text { Does not limit the liability due to } \\
\text { negligent or reckless activities. } \\
\text { Owners of wastewater treatment } \\
\text { plants remain liable. See } 403.064 \\
\text { about reuse of reclaimed waters. See } \\
\text { also "Laws regarding solid waste } \\
\text { management" and the use of sludge } \\
\text { (residuals) on farmland. }\end{array}$ & DEP \\
\hline
\end{tabular}




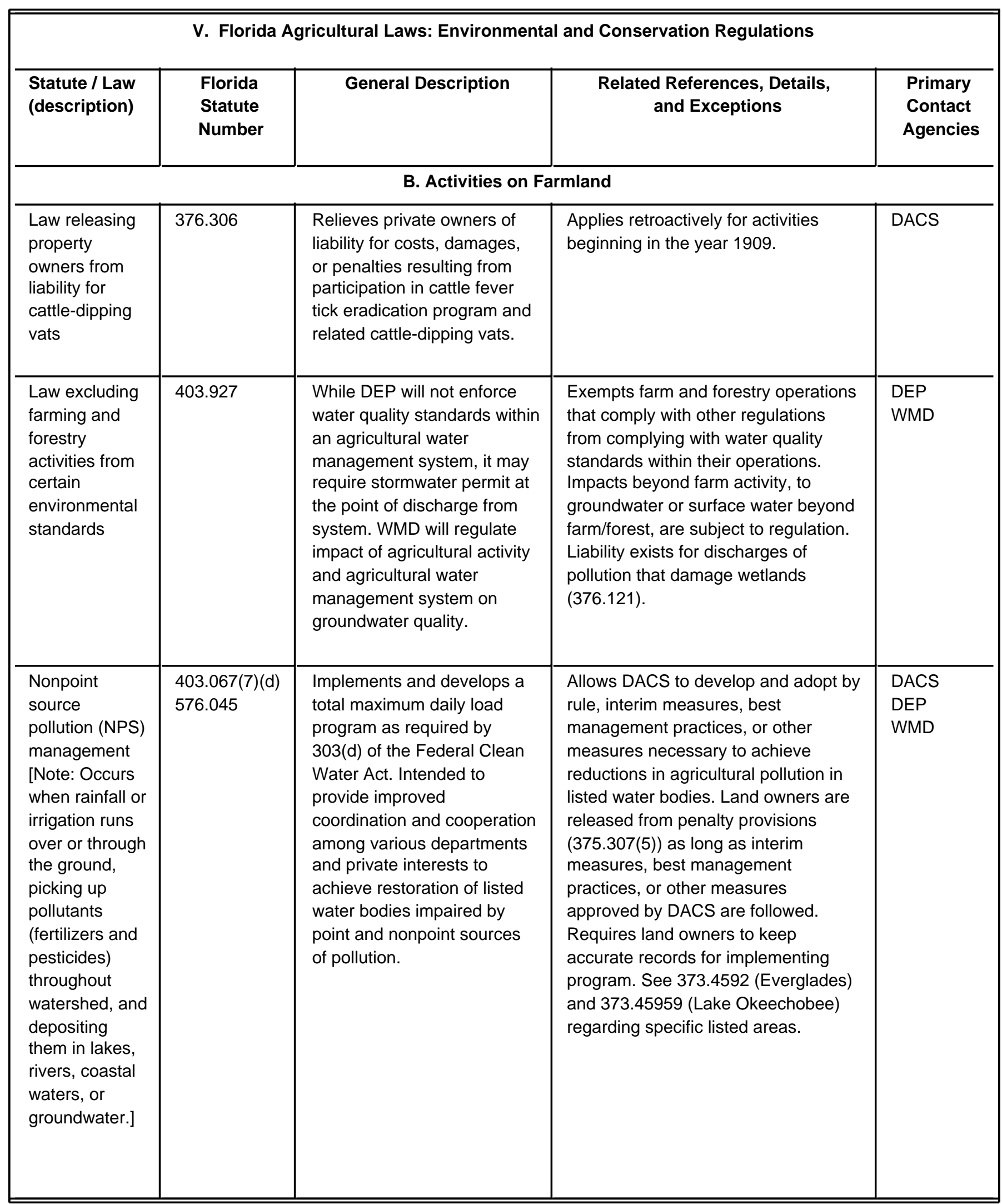




\begin{tabular}{|c|c|c|c|c|}
\hline \multicolumn{5}{|c|}{ V. Florida Agricultural Laws: Environmental and Conservation Regulations } \\
\hline $\begin{array}{l}\text { Statute / Law } \\
\text { (description) }\end{array}$ & $\begin{array}{l}\text { Florida } \\
\text { Statute } \\
\text { Number }\end{array}$ & General Description & $\begin{array}{l}\text { Related References, Details, } \\
\text { and Exceptions }\end{array}$ & $\begin{array}{l}\text { Primary } \\
\text { Contact } \\
\text { Agencies }\end{array}$ \\
\hline $\begin{array}{l}\text { Florida } \\
\text { Endangered } \\
\text { and } \\
\text { Threatened } \\
\text { Species Act of } \\
1977\end{array}$ & 372.072 & $\begin{array}{l}\text { Provides for research and } \\
\text { management to conserve } \\
\text { and protect endangered and } \\
\text { threatened species. }\end{array}$ & $\begin{array}{l}\text { Federal Endangered Species Act of } \\
1973 \text { supersedes state law. } 372.0725 \\
\text { states it is a third degree felony to kill } \\
\text { or wound any species that the FWC } \\
\text { designates as threatened, } \\
\text { endangered, or of special concern. } \\
372.073 \text { establishes a program to } \\
\text { reward informants of people violating } \\
\text { this Act. } 585.185-585.187 \text { deal with } \\
\text { endangered plants. } 373.414 \\
\text { considers adverse effects on } \\
\text { endangered, threatened, and special } \\
\text { concern species or their habitats as } \\
\text { one factor in permitting changes in } \\
\text { surface waters or wetlands (subject to } \\
\text { exemptions and mitigation). }\end{array}$ & $\begin{array}{l}\text { DPI } \\
\text { EPA } \\
\text { FWC }\end{array}$ \\
\hline $\begin{array}{l}\text { Laws regarding } \\
\text { solid waste } \\
\text { management }\end{array}$ & $\begin{array}{l}403.702- \\
403.7721\end{array}$ & $\begin{array}{l}\text { Regulates wastes, including } \\
\text { agricultural waste, municipal } \\
\text { waste, sludge, compost, } \\
\text { recyclable materials, used } \\
\text { motor oil, and yard waste. } \\
\text { Regulates waste handling, } \\
\text { classification, disposal and } \\
\text { recycling. }\end{array}$ & $\begin{array}{l}\text { Burning vegetative waste: Section } \\
403.702(2)(f) \text { allows burning of plant } \\
\text { and other material, but must comply } \\
\text { with local restrictions, which are often } \\
\text { stricter. Compost Law allows normal } \\
\text { composting of farm wastes produced } \\
\text { in normal farming operations when } \\
\text { applied to land where waste was } \\
\text { generated, but DEP prohibits using } \\
\text { compost to fill any surface water body } \\
\text { or applying a compost that would } \\
\text { endanger public health or the } \\
\text { environment. Wastewater Plant } \\
\text { Residuals (Sludge): DEP and local } \\
\text { governments regulate types of } \\
\text { residuals that can be applied. } \\
\text { Hazardous Waste: Hazardous waste } \\
\text { is also regulated by more restrictive } \\
\text { state and federal laws such as RCRA. }\end{array}$ & $\begin{array}{l}\text { DEP } \\
\text { EPA }\end{array}$ \\
\hline
\end{tabular}




\begin{tabular}{|c|c|c|c|c|}
\hline \multicolumn{5}{|c|}{ V. Florida Agricultural Laws: Environmental and Conservation Regulations } \\
\hline $\begin{array}{l}\text { Statute / Law } \\
\text { (description) }\end{array}$ & $\begin{array}{l}\text { Florida } \\
\text { Statute } \\
\text { Number }\end{array}$ & General Description & $\begin{array}{c}\text { Related References, Details, } \\
\text { and Exceptions }\end{array}$ & $\begin{array}{l}\text { Primary } \\
\text { Contact } \\
\text { Agencies }\end{array}$ \\
\hline $\begin{array}{l}\text { Laws regarding } \\
\text { pollutant } \\
\text { storage tank } \\
\text { systems }\end{array}$ & 376.303 & $\begin{array}{l}\text { Authorizes DEP to establish } \\
\text { rules regarding construction, } \\
\text { permitting, registration, and } \\
\text { record keeping for tanks that } \\
\text { hold pollutants such as oil, } \\
\text { gasoline, pesticide, chlorine, } \\
\text { and ammonia compounds. } \\
\text { Requires a procedure for } \\
\text { abandonment of pollutant } \\
\text { storage tanks. }\end{array}$ & $\begin{array}{l}\text { County regulations may be stricter } \\
\text { than state rules and should be } \\
\text { consulted. State rules do not require } \\
\text { DEP permit for above or below ground } \\
\text { tanks with a capacity of } 550 \text { gallons or } \\
\text { less that are used for agriculture } \\
\text { related storage. However, all tanks } \\
\text { are subject to spill reporting } \\
\text { requirements for spills over } 100 \\
\text { gallons to pervious surfaces. } \\
376.3071-376.3072 \text { pertain to } \\
\text { contamination from leaks and spills } \\
\text { from tanks, cleanup of contaminated } \\
\text { area, and liability for cleanup costs. }\end{array}$ & $\begin{array}{l}\text { DEP } \\
\mathrm{DOH}\end{array}$ \\
\hline $\begin{array}{l}\text { Laws regarding } \\
\text { onsite sewage } \\
\text { disposal }\end{array}$ & 381.0065 & $\begin{array}{l}\text { Authorizes } \mathrm{DOH} \text { to set } \\
\text { regulations for small onsite } \\
\text { sewage disposal systems. } \\
\text { DCF requires permits for } \\
\text { installation, repair, or } \\
\text { abandonment of all onsite } \\
\text { sewage systems. }\end{array}$ & $\begin{array}{l}\text { Counties often require separate } \\
\text { permits in addition to DCF permits. } \\
\text { DEP may further regulate systems } \\
\text { that process over } 10,000 \text { gallons of } \\
\text { domestic sewage per day. }\end{array}$ & $\begin{array}{l}\text { DCF } \\
\text { DEP } \\
\text { DOH }\end{array}$ \\
\hline \multicolumn{5}{|c|}{ C. Conservation of Soil, Water, Farmland, and Forests } \\
\hline $\begin{array}{l}\text { Laws regarding } \\
\text { soil and water } \\
\text { conservation }\end{array}$ & $\begin{array}{l}582.01- \\
582.49\end{array}$ & $\begin{array}{l}\text { Authorizes DACS to adopt } \\
\text { rules and implement } \\
\text { programs to control and } \\
\text { prevent soil erosion, thereby } \\
\text { preserving soils and other } \\
\text { natural resources. }\end{array}$ & $\begin{array}{l}\text { Provides for creation of a soil and } \\
\text { water conservation district } \\
\text { (582.10-582.14). A district may } \\
\text { conduct surveys, investigations, and } \\
\text { demonstrations, and may take certain } \\
\text { actions to control or prevent soil } \\
\text { erosion (582.20). A public referendum } \\
\text { must be held to approve any land use } \\
\text { regulation proposed by a district } \\
\text { (581.21-581.22). Provides for } \\
\text { discontinuance of a district by petition } \\
\text { and referendum (582.30). See } \\
2003-97, \text { amending } 582.10,582.30, \\
\text { changing the number of of land } \\
\text { owners from } 25 \text { to } 10 \% \text { within a } \\
\text { territory as needed to petition the } \\
\text { formation or closure of a soil and } \\
\text { water conservation district. }\end{array}$ & DACS \\
\hline
\end{tabular}




\begin{tabular}{|c|c|c|c|c|}
\hline \multicolumn{5}{|c|}{ V. Florida Agricultural Laws: Environmental and Conservation Regulations } \\
\hline $\begin{array}{l}\text { Statute / Law } \\
\text { (description) }\end{array}$ & $\begin{array}{l}\text { Florida } \\
\text { Statute } \\
\text { Number }\end{array}$ & General Description & $\begin{array}{c}\text { Related References, Details, } \\
\text { and Exceptions }\end{array}$ & $\begin{array}{l}\text { Primary } \\
\text { Contact } \\
\text { Agencies }\end{array}$ \\
\hline $\begin{array}{l}\text { Law regarding } \\
\text { conservation } \\
\text { easement }\end{array}$ & 704.06 & $\begin{array}{l}\text { Defines and establishes } \\
\text { rights and duties regarding } \\
\text { conservation easements. }\end{array}$ & $\begin{array}{l}\text { Conservation easements are } \\
\text { perpetual restrictions against } \\
\text { changing use of property from an } \\
\text { existing use, such as forest or farm, to } \\
\text { protect natural resources. A land } \\
\text { owner and a governmental or } \\
\text { charitable organization may agree for } \\
\text { the easement to provide for a } \\
\text { perpetual use of land that conserves } \\
\text { natural resources. }\end{array}$ & DACS \\
\hline \multicolumn{5}{|c|}{$\begin{array}{l}\text { NOTE: Environmental and conservation laws and regulations often are complex and controlled at the federal, state, } \\
\text { regional, and local levels. Penalties for violations of the law can be severe. This table gives an extremely brief review of the } \\
\text { major state laws that relate to agriculture. Farmers should check with the proper contact agencies or with local extension } \\
\text { agents to determine the requirements for complying with the law in a particular situation. }\end{array}$} \\
\hline
\end{tabular}

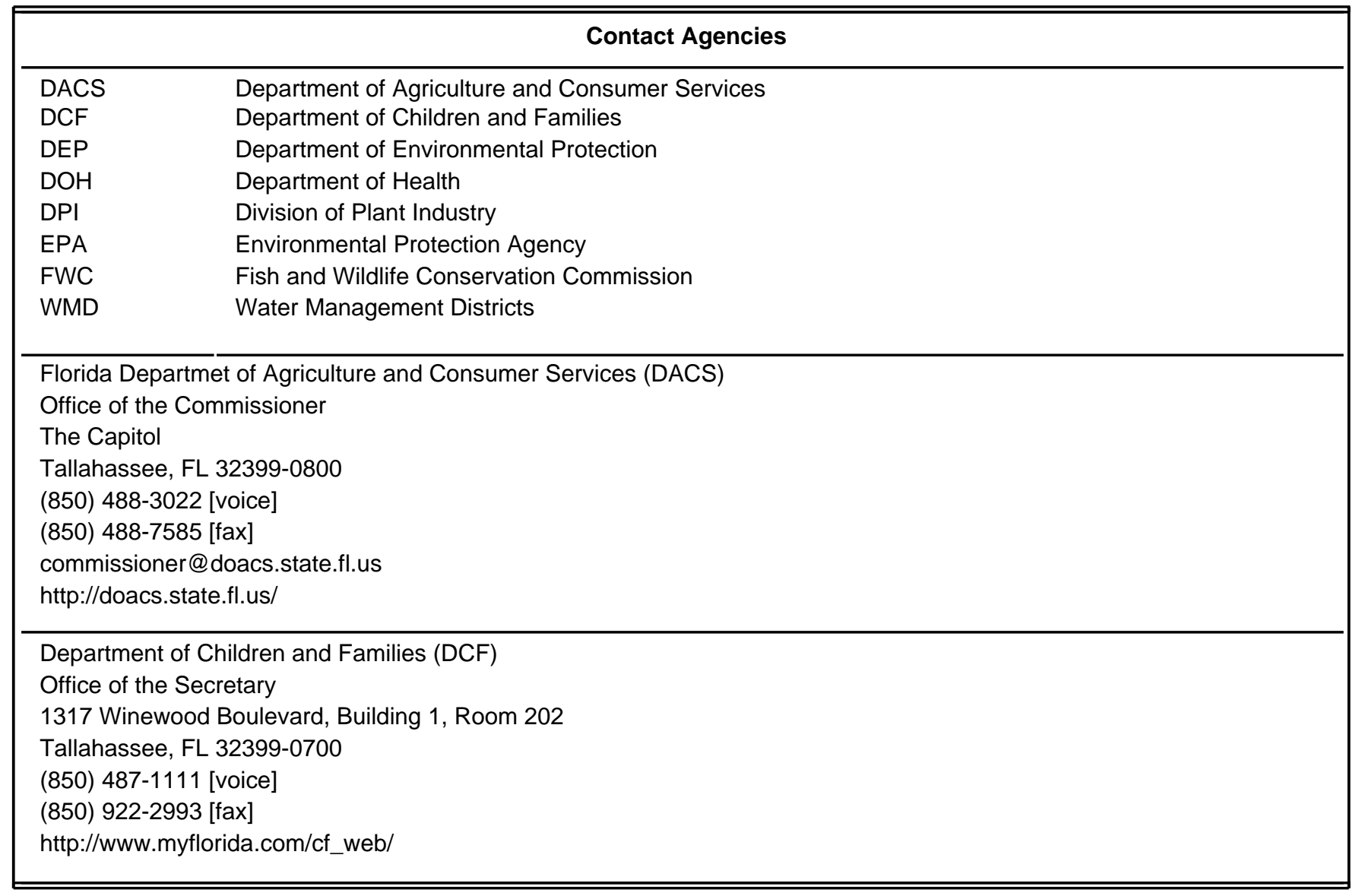




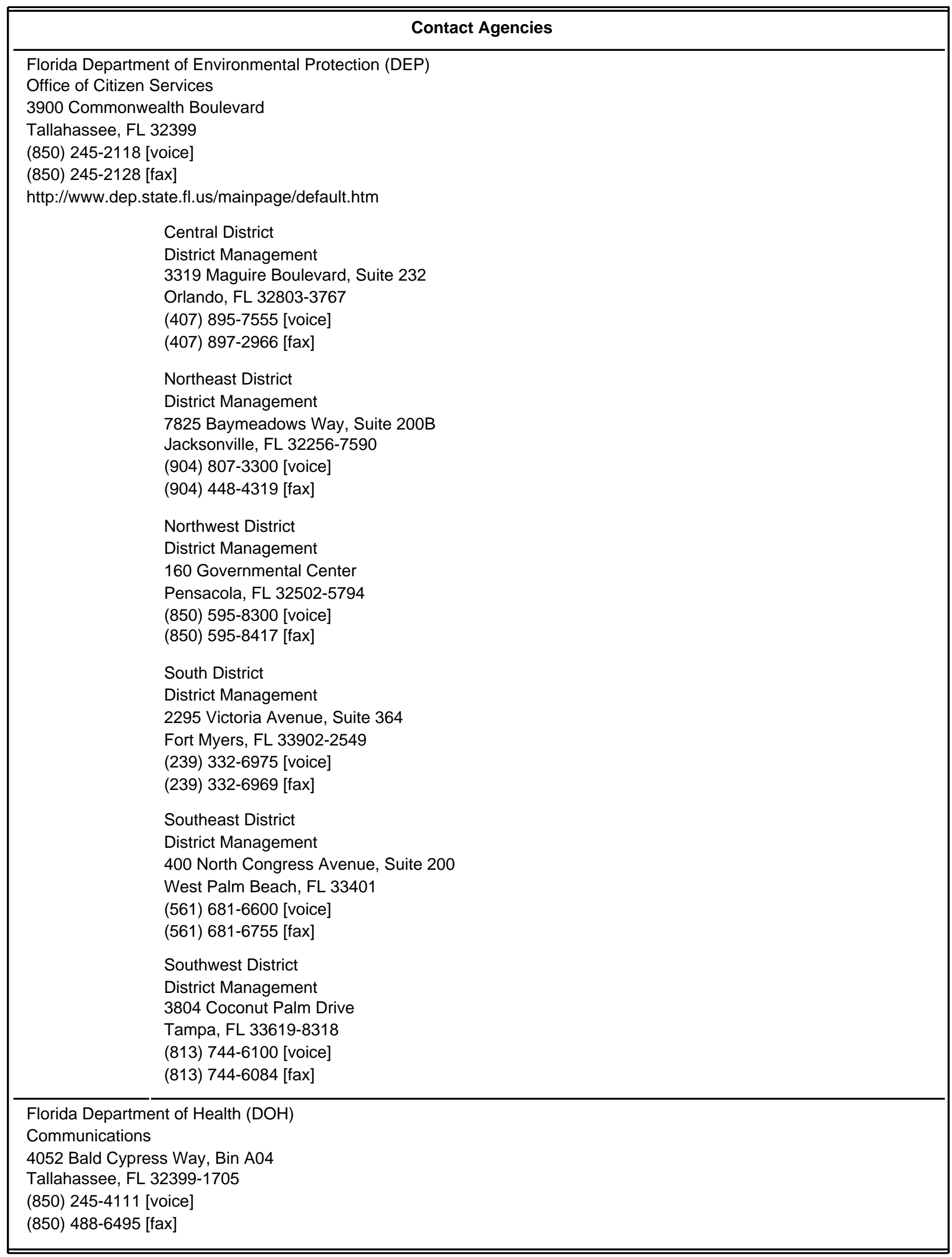




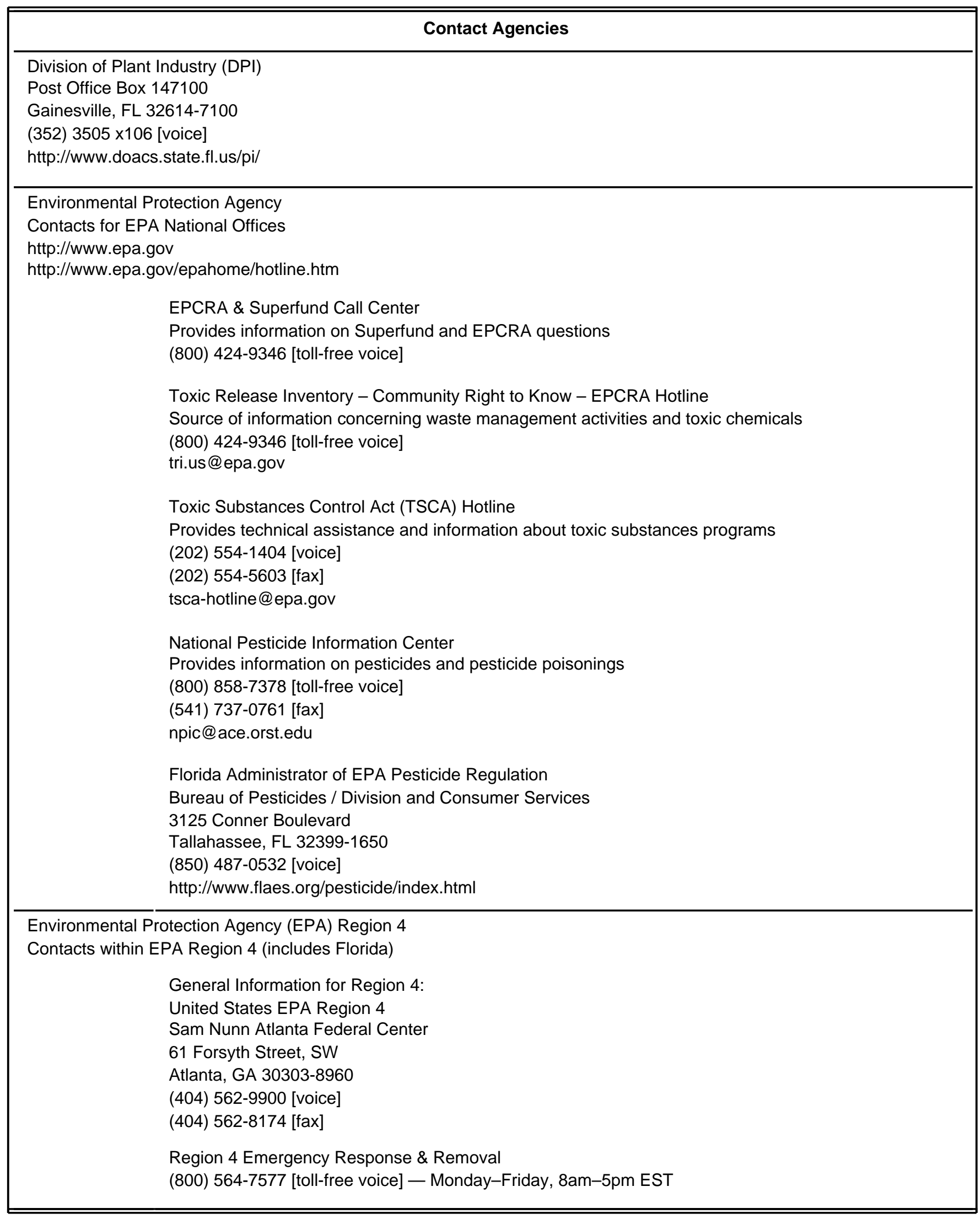




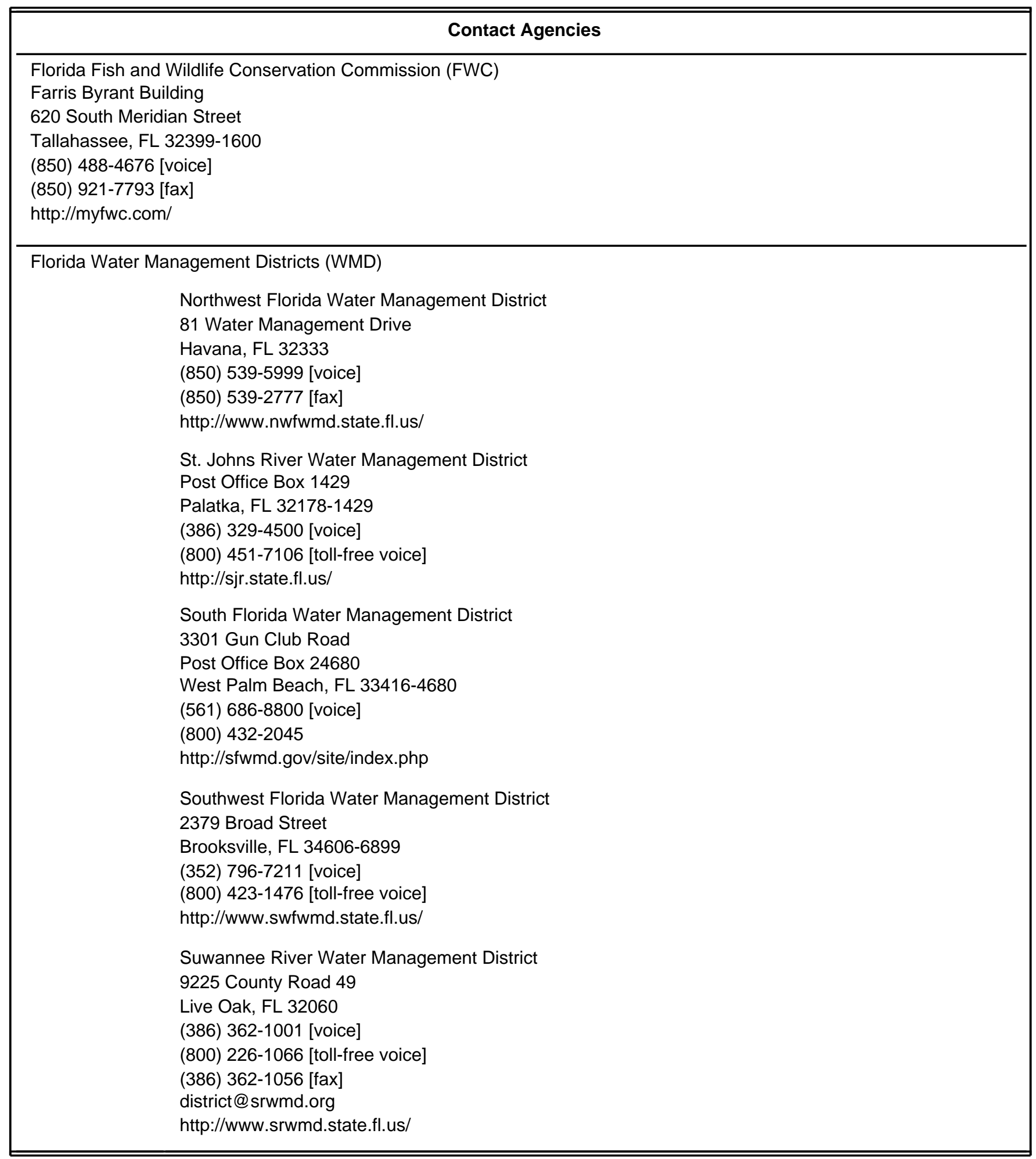

